\title{
Systemic and Local Humoral Immune Response against F-1 and LaSota Strains of New Castle Disease Virus in Chicken
}

\author{
Rajesh Singathia $^{1}$, Ravindra Sharma ${ }^{2}$ and Satishkumar Batra ${ }^{2}$ \\ ${ }^{1}$ Department of Veterinary Microbiology, College of Veterinary and Animal Sciences, \\ Navania, Vallabhnagar, Udaipur-313601 (Rajasthan), India \\ ${ }^{2}$ Department of Veterinary Microbiology, College of Veterinary Sciences, C.C.S. Haryana \\ Agricultural University, Hisar, India \\ *Corresponding author
}

\section{A B S T R A C T}

\section{Keywords}

Newcastle disease virus, Chicks, Humoral immunity, F-1 LaSota

Article Info

Accepted:

15 July 2019

Available Online:

10 August 2019
F-1 and LaSota strains of NDV were propagated in laboratory using 10-day old embryonated hen eggs via allantoic cavity route. One group of thirty chicks were infected with F-1strain and other with LaSota strain with $10^{5} \mathrm{egg}$ infective doses in $100 \mu \mathrm{l}$ of virus via oral and ocular route. Sequential sera samples and tracheal samples at day 0, 3,7,14, 21 and 28 post infection were collected and titre of antibodies indicative of humoral immune response was determined by indirect ELISA. The findings of present study lead to the conclusion that infection with NDV induces production of humoral immune response in chickens. Humoral antibodies generated in responses to NDV infection in chickens are both of local (IgA, IgG) and serum antibodies (IgG and IgM) type. The F-1 strain of NDV appears to be slightly better immunogenic than that of LaSota strain of NDV.

\section{Introduction}

Newcastle disease (ND) is an OIE listed and highly contagious viral disease affecting over 250 species of birds of all age groups (Alexander, 1997). ND is one of the lethal, zoonotic diseases causing colossal economic losses in poultry industry due to high morbidity and mortality. The disease is caused by a single stranded, enveloped, nonsegmented RNA virus i.e. avian paramyxovirus serotype-1 (APMV-1) classified under genus Avulavirus of family Paramyxoviridae (Mayo, 2002). The virus infection occurring through respiratory and/or gastrointestinal tract results in production of clinical signs accompanied with high mortality. Lesions of disease are mainly produced in respiratory, gastrointestinal and nervous system. Both inactivated and live attenuated virus vaccines are being used commercially for immunization of birds. The present study was planned to study the systemic and local humoral immune response 
against F-1 and LaSota strains of New castle disease virus (NDV) in chicken

\section{Materials and Methods}

\section{Virus}

A seed stock of F-1 and LaSota strain of NDV were procured in lyophilized form and propagated in 10-day old embryonated eggs via allantoic cavity route. A rapid slide haemagglutination (HA) test was performed on the allantoic fluid to confirm the presence of virus. The harvested allantoic fluid was purified by using standard methods. For use as antigen in ELISA, the purified virus was inactivated by exposing to ultraviolet light for 40 minute (Reynolds and Maraqa, 2000) and virus titration was performed by calculating the Egg infective dose $50\left(\mathrm{EID}_{50}\right)$ of both F-1 and LaSota strain in 10-day old embryonated chicken eggs by the standard method (Reed and Muench,1938).

\section{Experimental chicks}

Ninety broiler chicks were randomly divided into three groups of 30 birds each. Of these, one batch was vaccinated with F-1strain and second with LaSota strain with $10^{5} \mathrm{egg}$ infective doses in $100 \mu \mathrm{l}$ of virus via oral and ocular route. Third batch were kept as control.

\section{Collection of samples}

\section{Collection of serum}

Serum samples were collected from each of five randomly selected birds from each group at $0,3,7,14,21$ and 28 days using standard keys.

\section{Collection of tracheal exudates}

Tracheal exudates were obtained from five chickens from each group at $0,3,7,14,21$ and
28 days post inoculation of virus and stored frozen at $-20^{\circ} \mathrm{Ctill}$ further use.

\section{Indirect Enzyme linked immunosorbent assay (ELISA) for antibody assay}

Serum samples collected from immunized and control birds were subjected to indirect ELISA for measuring NDV specific serum immunoglobulins (Igs). The dilution of antigen, monoclonal antibody and conjugate was optimized by checker board titration of these reagents.

Micro ELISA polyvinyl plates (Nunc) were coated with optimum dilution (1:10) of NDV antigen in carbonate bicarbonate buffer and were incubated at $37^{\circ} \mathrm{C}$ for 1 hour (h) and then kept at $4^{0} \mathrm{C}$ overnight.

After three washing with Phosphate buffer saline (PBS) containing 0.05 percent $(\mathrm{v} / \mathrm{v})$ Tween-20 (PBST), which was the wash buffer used throughout, the plates were blocked using $100 \mu \mathrm{l}$ blocking buffer and incubated at $37^{\circ} \mathrm{C}$ for $1 \mathrm{~h}$. Thereafter, $50 \mu \mathrm{l}$ of double fold dilution of each serum sample (in duplicate) in blocking buffer was added and incubated at $37^{\circ} \mathrm{C}$ for $1 \mathrm{~h}$ followed by washing with PBST. The optimum dilution of monoclonal antibody (Kind Gift from Dr. R.C. Jones, University of Liverpool, U.K.) specific for chicken Igs were then added and incubated for $1 \mathrm{~h}$.

The plates were then washed thrice with PBST and $50 \mu \mathrm{l}$ of optimally diluted rabbit antimouse Igs Horse raddish peroxidase (HRPO) conjugate (Sigma Chemical Co.) was added in all the wells and incubated further for 45 minute at $37^{\circ} \mathrm{C}$. Plates were washed three times with PBST. Finally, $50 \mu$ l of freshly prepared substrate solution of orthophenylenediamine (OPD) (Sigma Chemical Co.) was added in each well and plates were left in dark for development of color reaction. The reaction was stopped by adding $50 \mu \mathrm{l}$ of $1 \mathrm{M}$ 
$\mathrm{H}_{2} \mathrm{SO}_{4} /$ well. The optical density of the wells was measured in an ELISA reader using 492 $\mathrm{nm}$ filter and titer was calculated (Khatri, 2000).

\section{Results and Discussion}

Humoral immune response against NDV was determined by assaying titre of different type of antibodies i.e. $\operatorname{IgG}, \operatorname{IgM}$ and $\operatorname{IgA}$ in serum and tracheal exudate of infected birds at different days post immunization (DPI). The antibody titre was determined by indirect ELISA using F-1 and LaSota strains of NDV as coating antigen and anti-chicken immunoglobulin monoclonals as tracing antibody.

Antibody titre in serum of broiler chicks immunized with different strains of NDV

ELISA IgG antibody titres in serum of broiler chicks immunized with different strains of NDV using F-1 strain of virus as coating antigen

Serum IgG antibody titres as determined by indirect ELISA on different DPI in different groups of broiler chicks are shown in table 1 . An increase in the serum IgG antibody titres in the group of birds infected with F-1 strain of NDV were observed on 7 DPI and remained so at 14 DPI which showed an increase on $21^{\text {st }}$ day and peaked on 28 DPI. Serum IgG antibody titre in the group of chicks infected with LaSota strain of NDV were observed on 3 DPI and remained at the same level up to 14 DPI which showed an increase on day 21 and peaked on $28^{\text {th }}$ DPI. In the serum from control group of birds, there was no detectable serum IgG antibody titre. The groups inoculated with F-1 or LaSota showed a significant higher antibody titre $(\mathrm{P}<0.05)$ than that of control. No significant variation was observed in serum IgG titres with in birds immunized with F-1 or LaSota strain of NDV.
ELISA IgM antibody titres in serum of broiler chicks immunized with different strains of NDV using F-1 strain of virus as coating antigen

ELISA IgM antibody titres in serum of different groups of broiler chicks on different DPI are shown in Table 2. An increase in the serum IgM antibody titres in the group of birds infected with F-1 strain of NDV were observed on 3 DPI and remained so at 7 DPI, peaked on day $14^{\text {th }}$ followed by a decline by 28 DPI. The serum IgM antibody titres in the group of chicks immunized with LaSota strain of NDV were above that of control birds on $3{ }^{\text {rd }}$ DPI and remained almost at the same level up to day 7 post infection, peaked on $14^{\text {th }}$ day followed by a decline by 28 DPI. The titre of serum $\operatorname{IgM}$ antibodies in birds immunized with either F-1 or with LaSota strain of NDV did not exhibit any statistical significant $(\mathrm{P}<0.05)$ difference at various time intervals of serum testing but these were significantly different $(\mathrm{P}<0.05)$ as compared to that of control birds.

Antibody concentration in tracheal exudates of broiler chicks immunized with different strains of NDV

ELISA IgA antibody O.D. values in tracheal exudates of broiler chicks immunized with different strains of NDV using F-1 strain of virus as coating antigen

The effect of immunization with different strains of NDV on induction of IgA antibody responses in tracheal exudates in different groups of broiler chicks on different DPI are shown in Table 3.A rise in $\operatorname{IgA}$ antibody optical density (O.D.) values in tracheal washing of birds belonging to group inoculated with F-1 strain was recorded on 7 DPI which peaked on $14^{\text {th }}$ day and remained at almost the same level upto 28 DPI. The IgA 
antibody O.D. in immunized chicks were significantly higher $(\mathrm{P}<0.05)$ compared to that of control chicks on $7 \& 14$ DPI.A rise in $\operatorname{IgA}$ antibody O.D. values in birds immunized with LaSota strain of NDV was observed on 7 DPI followed by an increase on day 14. It peaked on $28^{\text {th }}$ DPI. Responses of immunized chicks were slightly higher as compared to that of control chicks but statistically these differences were found to be insignificant

IgG antibody ELISA O.D. in tracheal exudates of broiler chicks immunized with different strains of NDV using F-1 strain of virus as coating antigen

IgG antibody O.D. values as obtained in ELISA test in different groups of broiler chicks immunized with either F-1 or LaSota strain of NDV at different DPI are shown in table 4.A higher than control IgG antibody O.D. value and hence the antibody concentration in the group immunized with F1 strain was detected on 14 DPI and it peaked at 28 DPI. The O.D. values of immunized chicks were significantly higher $(\mathrm{P}<0.05)$ when compared with that of control chicks on 7, 14 and 28 DPI.

A similar pattern of ascending O.D. values was noted in tracheal exudates of birds inoculated with LaSota strain. The O.D. values of immunized chicks were significantly higher $(\mathrm{P}<0.05)$ as compared with that of control chicks on $7^{\text {th }}$ and $28^{\text {th }}$ DPI.

Table.1 ELISA IgG antibody titres in serum of broiler chicks immunized with different strains of NDV using F-1 strain of virus as coating antigen

\begin{tabular}{|c|c|c|c|c|c|c|c|}
\hline \multicolumn{8}{|c|}{ Serum antibody titres $\left(\log _{10}\right)$} \\
\hline \multirow[b]{2}{*}{ Groups } & \multicolumn{7}{|c|}{ Days post immunization } \\
\hline & $\mathbf{0}$ & 3 & 7 & & 14 & 21 & 28 \\
\hline Control & $\begin{array}{l}<1.30^{\mathrm{A}}= \\
0.00\end{array}$ & $\begin{array}{l}<1.30^{\mathrm{A}}= \\
0.00\end{array}$ & $\begin{array}{l}<1.30^{\mathrm{B}} \\
0.00\end{array}$ & & $\begin{array}{l}<1.30^{\mathrm{A}} \pm \\
0.00\end{array}$ & $\begin{array}{l}<1.30^{\mathrm{C}} \pm \\
0.00\end{array}$ & $\begin{array}{l}<1.30^{\mathrm{B}} \pm \\
0.00\end{array}$ \\
\hline F-1 & $\begin{array}{l}<1.30^{\mathrm{A}} \\
0.00\end{array}$ & $\begin{array}{l}1.42^{\mathrm{A}} \\
0.07\end{array}$ & $\begin{array}{l}1.60^{\mathrm{A}} \\
0.09\end{array}$ & \pm & $\begin{array}{l}1.60^{\mathrm{A}} \quad \pm \\
0.10\end{array}$ & $\begin{array}{l}2.02^{\mathrm{A}} \quad \pm \\
0.07\end{array}$ & $\begin{array}{l}2.32^{A} \\
0.12\end{array}$ \\
\hline LaSota & $\begin{array}{l}<1.30^{\mathrm{A}} \\
0.00\end{array}$ & $\begin{array}{l}1.54^{\mathrm{A}} \\
0.11\end{array}$ & $\begin{array}{l}1.48^{\mathrm{AB}} \\
0.07\end{array}$ & & $\begin{array}{l}1.54^{\mathrm{A}} \\
0.18\end{array}$ & $\begin{array}{l}1.66^{\mathrm{B}} \\
0.11\end{array}$ & $\begin{array}{l}2.20^{A} \\
0.10\end{array}$ \\
\hline
\end{tabular}

Means with the same letter are not significantly different $(\mathrm{P}<0.05)$

Table.2 ELISA IgM antibody titres in serum of broiler chicks immunized with different strains of NDV using F-1 strain of virus as coating antigen

\begin{tabular}{|c|c|c|c|c|c|c|}
\hline \multicolumn{7}{|c|}{ Serum antibody titres $\left(\log _{10}\right)$} \\
\hline \multirow[t]{2}{*}{ Groups } & \multicolumn{6}{|c|}{ Days post immunization } \\
\hline & 0 & 3 & 7 & 14 & 21 & 28 \\
\hline Control & $\begin{array}{l}<1.30^{\mathrm{A}} \quad \pm \\
0.00\end{array}$ & $\begin{array}{l}<1.30^{\mathrm{B}} \quad \pm \\
0.00\end{array}$ & $\begin{array}{l}<1.30^{\mathrm{C}} \quad \pm \\
0.00\end{array}$ & $\begin{array}{l}<1.30^{\mathrm{B}} \quad \pm \\
0.00\end{array}$ & $\begin{array}{l}<1.30^{\mathrm{B}} \\
\pm 0.00\end{array}$ & $\begin{array}{l}<1.30^{\mathrm{A}} \\
\pm 0.00\end{array}$ \\
\hline F-1 & $\begin{array}{l}<1.30^{\mathrm{A}} \quad \pm \\
0.00\end{array}$ & $\begin{array}{l}1.78^{\mathrm{A}} \\
0.15\end{array}$ & $\begin{array}{l}1.72^{\mathrm{A}} \quad \pm \\
0.07\end{array}$ & $\begin{array}{l}2.20^{\mathrm{A}} \\
0.10\end{array}$ & $\begin{array}{l}1.90^{\mathrm{A}} \\
0.10\end{array}$ & $\begin{array}{l}1.68^{A} \\
0.14\end{array}$ \\
\hline LaSota & $\begin{array}{l}<1.30^{\mathrm{A}} \quad \pm \\
0.00\end{array}$ & $\begin{array}{l}1.60^{\mathrm{AB}} \pm \\
0.19\end{array}$ & $\begin{array}{l}1.53^{\mathrm{B}} \\
0.08\end{array}$ & $\begin{array}{l}2.26^{\mathrm{A}} \\
0.11\end{array}$ & $\begin{array}{l}1.78^{A} \\
0.12\end{array}$ & $\begin{array}{l}1.54^{\mathrm{A}} \\
0.18\end{array}$ \\
\hline
\end{tabular}

Means with the same letter are not significantly different $(\mathrm{P}<0.05)$ 
Table.3 ELISA IgA antibody O.D. values in tracheal exudates of broiler chicks immunized with different strains of NDV using F-1 strain of virus as coating antigen

\begin{tabular}{|l|l|l|l|l|}
\hline \multicolumn{5}{|c|}{ O. D. values } \\
\hline Groups & $\mathbf{3}$ & $\mathbf{7}$ & $\mathbf{1 4}$ & $\mathbf{2 8}$ \\
\hline Control & $0.03^{\mathrm{A}} \pm 0.00$ & $0.03^{\mathrm{B}} \pm 0.00$ & $0.04^{\mathrm{B}} \pm 0.00$ & $\mathbf{0 . 0 3}^{\mathbf{A}} \pm \mathbf{0 . 0 0}$ \\
\hline F-1 & $0.02^{\mathrm{A}} \pm 0.01$ & $0.13^{\mathrm{A}} \pm 0.03$ & $0.26^{\mathrm{A}} \pm 0.06$ & $\mathbf{0 . 2 7}^{\mathbf{A}} \pm \mathbf{0 . 1 2}$ \\
\hline LaSota & $\mathbf{0 . 0 2} \pm \mathbf{0 . 0 1}$ & $\mathbf{0 . 0 7}^{\mathbf{A B}} \pm \mathbf{0 . 0 2}$ & $\mathbf{0 . 1 7}^{\mathbf{A B}} \pm \mathbf{0 . 0 6}$ & $\mathbf{0 . 1 8}^{\mathbf{A}} \pm \mathbf{0 . 0 4}$ \\
\hline
\end{tabular}

Means with the same letter are not significantly different $(\mathrm{P}<0.05)$

Table.4 ELISA IgG antibody O.D. in tracheal exudates of broiler chicks immunized with different strains of NDV using F-1 strain of virus as coating antigen

\begin{tabular}{|l|l|l|l|l|}
\hline \multicolumn{5}{|c|}{ O. D. values } \\
\hline Groups & $\mathbf{3}$ & $\mathbf{7}$ & $\mathbf{1 4}$ & $\mathbf{2 8}$ \\
\hline Control & $0.03^{\mathrm{A}} \pm 0.00$ & $0.03^{\mathrm{B}} \pm 0.00$ & $0.04^{\mathrm{B}} \pm 0.00$ & $\mathbf{0 . 0 3}^{\mathrm{B}} \pm \mathbf{0 . 0 0}$ \\
\hline F-1 & $0.04^{\mathrm{A}} \pm 0.00$ & $0.11^{\mathrm{A}} \pm 0.01$ & $0.23^{\mathrm{A}} \pm 0.05$ & $\mathbf{0 . 2 6}^{\mathrm{A}} \pm \mathbf{0 . 0 2}$ \\
\hline LaSota & $\mathbf{0 . 0 4}^{\mathrm{A}} \pm \mathbf{0 . 0 1}$ & $\mathbf{0 . 1 0}^{\mathbf{A}} \pm \mathbf{0 . 0 1}$ & $\mathbf{0 . 1 1}^{\mathrm{B}} \pm \mathbf{0 . 0 1}$ & $\mathbf{0 . 2 5}^{\mathbf{A}} \pm \mathbf{0 . 0 3}$ \\
\hline
\end{tabular}

Means with the same letter are not significantly different $(\mathrm{P}<0.05)$

The present study was undertaken to investigate the kinetics of humoral mediated immune response against NDV infection in broiler chicken.

The oral and conjunctival route has been used to immunize the chicks with either F-1 or LaSota strain of NDV. Both these routes of immunization have previously been used successfully by the other workers (Reynolds and Maraqa, 2000; Reetha et al., 2001; AlGarib et al., 2003a; Zoth et al., 2008).

In the present study, an increase in $\mathrm{IgG}$ antibody titre in sera of broiler chicks immunized with LaSota or F-1 strain of NDV was detectable at $3^{\text {rd }}$ and $7^{\text {th }}$ day post immunization (DPI), respectively. The antibody titre increased gradually and peaked on $28^{\text {th }}$ (DPI). Our finding support the earlier findings of Zoth et al., (2008) who reported that $\mathrm{IgG}$ induced by low virulent virus was detectable at day 7 post vaccination. Further the present study also confirm the observation of Marquardt et al., (1985)who reported that the ELISA and HI titres responses began at 7 DPI, rose moderately and peaked at $21^{\text {st }}$ day in the chicks vaccinated at $2^{\text {nd }}$ week by nostril and eye route method. Similarly, our findings are in conformation with the findings of Ratnaparkhe et al., (1981) who reported that the HI antibody response increased and 
reached a peak at $3^{\text {rd }}$ and $4.5^{\text {th }}$ week after vaccination with LaSota strain of NDV inoculated with $10^{7.2} \mathrm{EID}_{50}$ per chick at 3 week of age by oral and oculonasal route, respectively. Our finding is also supported by similar observation of Sharma and Singh (1986) who reported that the HI antibody titre started to increase after vaccination and reached a peak (20.8) on $28^{\text {th }}$ day in the chicks $\left(6^{\text {th }}\right.$ day of age) infected intranasally and intraocularly. Similarly, Rahman et al., (2004) showed that HI titre, in chickens $\left(7^{\text {th }}\right.$ day of age) immunized with $\mathrm{V}_{4} \mathrm{HR}-\mathrm{ND}$ vaccine by eye drops route of inoculation, had significantly $(\mathrm{p}<0.01)$ increased and reached maximum $(5.07 \pm 0.50)$ on $38^{\text {th }}$ day of age. Similarly, Tanwani and Malik (1978) also found that chicks vaccinated with different vaccines by intranasal and intramuscular routes showed satisfactory $\mathrm{HI}$ antibody titres from $2^{\text {nd }}$ to $6^{\text {th }}$ months of their age and after that a gradual fall was observed. Otim et al., (2005) also reported that HI antibody titres started to increase and then peaked on 2 week, then declined after vaccination with LaSota vaccine in the village chicks (3 week old). Russell and Ezeifeka (1995) showed that in chicks (3 day old) immunized with Hitchner B1 strain of NDV by oculotopical route, serum IgG antibody response first detectable on $8^{\text {th }}$ day after vaccination continued to rise in the titre.

Our findings are in agreement with that of Mast et al., (2006) who observed that in chicks receiving $10^{8} \mathrm{EID}_{50}$ of $\mathrm{F}+\mathrm{HN}$ mutant, the virus specific $\operatorname{IgG}$ antibodies were detectable at day 4 post infection which gradually increased with age, together with the increasing HI titres which peaked on 14 day post infection, indicating isotype switching and active production of NDVspecific IgG. Similarly, Al-Garib et al., (2003b) reported that after inoculation with live NDV virus (LaSota and Roakin) by oculo-nasal route, an increase in antibody titre of the $\mathrm{IgG}, \operatorname{IgA}$ class and $\mathrm{HI}$ antibodies was detectable at day 7 post immunization (PI) in serum and plateau reached a peak on day 14 . Similarly, Mishra et al., (1985) reported that chicken vaccinated with different strains of $\mathrm{NDV}$, a maximum antibody titre of 2560 as estimated by ELISA was detectable between $14^{\text {th }}$ and $21^{\text {st }}$ days post vaccination. Mast $e t$ al., (2005) have reported that after intranasal inoculation with LaSota strains of NDV, a highest IgG antibody titre was observed on day 15 post infection. Similarly, Dandapat et al., (2005) observed that in chicks immunized with conventional RDF vaccine through occulo nasal route, the peak HI antibody was $\log _{2} 6.22$ at $2^{\text {nd }}$ week PI which again increased at $4^{\text {th }}$ week PI after receiving booster dose. This was followed by a gradual decline to $\log _{2} 5.4$ at $6^{\text {th }}$ week PI. Similarly, Kumar et al., (1988) have shown that one week after vaccination of birds with LaSota strain of NDV, the HI antibodies reached a titre of $3.0 \operatorname{logs}$ which peaked on $3^{\text {rd }}$ week (4.5 logs) and then declined to $1.0 \log$ by $9^{\text {th }}$ week post exposure. The observations of Linghua et al., (2007) that chicks vaccinated with NDV vaccine remained serologically negative for virus specific antibodies when tested by ELISA test are in contrast to finding of the present study where $\operatorname{IgG}$ response was observed in chicks from day 3 onwards. Ewert et al., (1979) reported that HI antibody in birds which were immunized at $6^{\text {th }}$ week of age by intramuscular or local (intratracheally + intranasally) route increases after immunization and reached maximum values on $10^{\text {th }}$ and $14^{\text {th }}$ days post vaccination, respectively. Lambrecht et al., (2004) reported an increase in the $\mathrm{HI}$ antibody titre which peaked on $3^{\text {rd }}$ or $4^{\text {th }}$ week after vaccination with live NDV vaccine or killed vaccine respectively.

Similarly, Chandrasekar et al., (1988) observed that in chicks (4 day old) immunized with RDVF by intranasal route developed a 
gradual increase in HI antibodies level from the first to $4^{\text {th }}$ week, followed by a fall upto $8^{\text {th }}$ week of immunization. Similar findings have been reported by Shuaib et al., (2006) and Satyanarayana and Reddy (1977). Similarly, Hilgers et al., (1998) found increase in $\mathrm{HI}$ antibody titre in chicks which were vaccinated with inactivated NDV by intramuscular route. Carrasco et al., (2008) found that after infection with Sao Joao do Meriti strain of NDV, HI titre started to rise and were maximum at day 21 or 35 DPI. A similar observation has been reported by Spradbrow et al., (1987).

The IgM antibodies are the first to be made by the $\mathrm{B}$ cells in response to any microbial infection which later on switch to $\operatorname{IgG}$ or any other isotype. The IgM antibody titre in serum of broiler chicks immunized with F-1 and LaSota strains of NDV were detectable at $3{ }^{\text {rd }}$ DPI and peaked on day 14 post infection. These results corroborate the finding of Mast et al., (2006) who reported a NDV-specific IgM response which peaked around 14 days of age in chicks vaccinated at embryonic day 18 with $10^{3}$ and $10^{4} \mathrm{EID}_{50}$ of the $\mathrm{F}+\mathrm{HN}$ mutant. Similarly, Al-Garib et al., (2003b) reported that after inoculation with live NDV virus (LaSota and Roakin) by oculo-nasal route, an increase in antibody titre of the $\operatorname{IgM}$ class of immunoglobulin was detectable at day $4^{\text {th }}$ PI in serum and reached a plateau level at $7^{\text {th }}$ DPI. Mast et al., (2005) have reported that in one day old chicks after intranasal inoculation with $10^{6} \mathrm{EID}_{50}$ of LaSota strain of NDV, IgM antibody responses were highest on $10^{\text {th }}$ day post infection. The variation in peak IgM antibody responses observed may be due to a different route of inoculation adopted by the investigators. Russell and Ezeifeka (1995) showed that in chicks (3 day old) immunized with Hitchner B1 strain of NDV by oculotopical route, serum IgM antibody response was first detectable on $5^{\text {th }}$ day after vaccination and it peaked $(3.5 \log 10)$ on $8^{\text {th }}$ DPI. The difference in peak in antibody titre may be attributed to the use of different strain of NDV.

Apart from serum IgM and IgG responses, production of local immune response in the form of $\operatorname{IgA}$ and $\operatorname{IgG}$ antibodies was also investigated in the present study.

In the present study, a detectable increase in the $\operatorname{IgA}$ O.D. values was observed at day $7^{\text {th }}$ PI which peaked at day 14 PI. A similar observation has been made by Al-Garib et al., (2003b) who reported that after inoculation with live NDV by oculo-nasal route, IgA response rose at day 4 post exposure (PE) and reached a plateau at day $7 \mathrm{PE}$ and then declined. Similarly, Jayawardne and Spradbrow (1995) also reported an increase in IgA antibody titre in tracheal washings, intestinal washings and lachrymal fluid after vaccination by intra crop and eye drop inoculation. In the present study, a low level of $\operatorname{IgA}$ O.D. values observed in tracheal exudates might be due to dilution of local antibodies associated with the method of collection. In contrast to our finding, Perozo et al., (2007) found that IgA antibody level remained undetectable upto day 35 DPI after in ovo vaccination with recombinant avian adeno-associated vaccine (rAAAV) coding for NDV haemagglutin in neuramindase. The delay in mounting of IgA antibody response was attributed to the failure of recombinant vaccine virus to stimulate a measurable mucosal immune response by itself, probably due to the nature of the antigenic stimulation induced by the rAAAV which is a replication defective virus and is dependent upon host cell machinery to express the $\mathrm{HN}$ antigen.

The presence of $\operatorname{IgG}$ antibodies was also detected in tracheal exudates during the present study. A higher IgG specific O.D. value detectable at day $7^{\text {th }}$ PI was observed. It 
then showed ascending pattern and reached a peak at day 28 PI. This result conforms to the findings of Ewert and Eidson (1977), who also observed a similar pattern of $\mathrm{IgG}$ antibody concentration and postulated that the Igs other than IgA may have a role in the protection of tracheal mucosa. Similarly, AlGarib et al., (2003b) reported that after inoculation with live NDV by oculo-nasal route; a higher $\operatorname{IgG}$ antibody titre was detected on $7^{\text {th }}$ DPI which reached a plateau at $14^{\text {th }}$ DPI. Zoth et al., (2008) have reported a similar finding that a significant higher $\operatorname{IgG}$ antibody response was detected on day $21^{\mathrm{st}}$ in tracheal swabs from the birds immunized with live NDV vaccine by eye drop route of inoculation. Ewert et al., (1979) reported that anti-NDV IgA and anti-NDV IgG levels increased after immunization and reached maximum values between 10 and 14 days post vaccination in birds which were immunized at $6^{\text {th }}$ week of age by intramuscularly or intratracheally and intranasal route.

The results of the present study indicate that humoral components of immune system are stimulated by the vaccine virus. The humoral components of the immune system respond by production of both local antibodies ( $\operatorname{Ig} \mathrm{A}$ and $\mathrm{IgG}$ ) and systemic or serum antibodies such as IgG and IgM. The F-1 strain of NDV appears to be more immunogenic than LaSota strain of NDV. No attempt was made during the present study to isotype the antibodies produced. Investigation of the isotype of antibodies produced in response to NDV virus will further help in understanding the mechanism of immune response generated during NDV infection/vaccination.

\section{Acknowledgment}

The Authors thanks the Dean, College of Veterinary Sciences, C.C.S. Haryana Agricultural University, Hisar for providing necessary facilities for this study.

\section{References}

Alexander, D.J. 1997. Newcastle disease and other avian paramyxoviridae infections. In: Diseases of Poultry. $10^{\text {th }}$ ed. Calnek, B.W., Barnes, H.J., Beard, C.W., McDougald, L.R., Saif, Y.M. (eds.). Ames, IA: Iowa State University Press. pp. 541-569.

Al-Garib, S.O., Gielkens, A.L.J.,Gruys, E. and Kochi, G. 2003a. Review of Newcastle disease virus with particular references to immunity and vaccination. World Poult. Sci. J.59:185-200.

Al-Garib, S.O., Gielkens, A.L.J.,Gruys, E., Hartog, L. and Kochi, G. 2003b. Immunoglobins class distribution of systemic and muosal antibody response to Newcastle disease in chickens. Avian Dis.47: 32-40.

Carrasco, A.D.O.T., Seki, M.C., Raso, T.D.F., Paulillo, A.C. and Pinto, A.A. 2008. Experimental infection of Newcastle disease virus in pigeons (Columba livia): Humoral antibody response, contact transmission and viral genome shedding.Vet. Microbial.129: 89-96.

Chandrasekar, S., Venkatesan, R.A., Padamanaban, V.D. andMasiilamony, P.R. 1988. Humoral immune response to Ranikhet disease virus vaccine in chicks. Indian Vet. J. 65: 653-657.

Dandapat, S., Nagarajan, K., Kataria, J.M., Bash, B.B. and Yadav, M.P. 2005. Humoral and cell mediated immune response to Ranikhet disease vaccine delivered through PLG microspheres in broiler chickens. Indian J. Poult. Sci. 40(1): 47-51.

Ewert, D.L. and Eidson, C.S. 1977. Effect of bursectomy and depletion of immunoglobulin A on antibody production and resistance to respiratory challenge after local or systemic vaccination of chickens with Newcastle 
disease virus. Infect. Immun. 18: 146150.

Ewert, D.L., Barger, B.O. and Eidson, C.S. 1979. Local antibody synthesis to Newcastle disease virus by solid-phase radioimmunoassay and immunofluorescene with classicalspecific antibody for chicken immunoglobulins. Infect. Immun.24(1): 269-275.

Hilgers, L.A.T., Nicolas, I., Lejeune, G., Dewil, E. and Boon, B. 1998.Effect of various adjuvants on secondary immune response in chickens. Vet. Immunol.Immunopathol.66:159-171.

Jayawardne, G.W.L. and Spradbrow, P.B. 1995. Mucosal immunity in chickens vaccinated with $\mathrm{V}_{4}$ stain of Newcastle disease virus. Vet. Microbiol.46: 69-77.

Khatri, M. 2000. Studies on natural and vaccine immunity against foot and mouth disease virus in calves. Ph.D. Thesis, CCS Haryana Agricultural university, Hisar.

Kumar, K.U., Swamy, S.K. and Reddy, T.V. 1988.Humoral and cell-mediated immune response in chicks vaccinated against Newcastle disease. Kerala J. Vet. Sci.19(2): 116-121.

Lambrecht, B., Gonze, M., Meulemans, G. and Van de berg, T.P. 2004. Assesment of the cell-mediated immune response in chickens by detection of chickens interferon- $\gamma$ in response to mitogen and recall Newcastle disease viral antigen stimulation. Avian Pathol., 33(3): 343350 .

Linghua, Z.,Xingshan, T. and Fengzhen, Z. 2007. Vaccination with Newcastle disease vaccine and $\mathrm{CpG}$ oligodeoxynucleotides induces specific immunity and protection against Newcastle disease virus in SPF chicken. Vet. Immunol. Immunopathol. 115: 216-222.

Marquardt, W.W., Synder, D.B., Savage,
P.K., Kadavil, S.K. and Yancey, F.S. 1985. Antibody response to Newcastle disease virus given by two different routes as measured by ELISA and Hemagglutination- inhibiton test and associated tracheal immunity. Avian Dis. 29(1): 71-79.

Mast, J., Nanbru, C., Decaesstecker, M., Lambrecht, B., Couvreur, B., Meulemans, G. and Van den berg, T. 2006. Vaccination of chickens embryos with escape mutants of LaSota Newcastle disease virus induces a protective immune response. Vaccine. 24: $1756-1765$.

Mast, J., Nanbru, C., Van Den Berg, T. and Meulemans, G. 2005. Ultrastructual changes of the tracheal epithelium after vaccination of day-old chicks with LaSota strain of the Newcastle disease virus. AvainPathol.42: 559-565.

Mayo, M.A. 2002. A summary of the taxonomic changes recently approved by ICTV.Arch.Virol. 147: 1655-1663.

Mishra, S.C., Rai, A. and Jaiswal, T.N. 1985. An enzyme linked immunosorbent assay for estimation of antibodies to Newcastle disease virus strains. Acta.Virol.29:151-157.

Otim, M.O., Mukiibi-Muka, G., Christensen, H. and Bisgaard, M. 2005.Aflatoxicosis, infectious bursal disease and immune response to Newcastle disease vaccination in rural chickens.Avian Pathol.34(4): 319-323.

Perozo, F., Finol, G. and Mavárez, Y. 2007. Levels of Immunoglobulin-A in trachea, gut and Bile samples of chickens vaccinated against Newcastle Disease. Rev. Cient. (Maracaibo).17(3): 226230.

Rahman, M.B., Rahman, M.M., Rahman, M., Kabir, S.M.L., Nazir, K.H.M.N.H. and Amin, M.M. 2004. Efficacy of $\mathrm{V}_{4} \mathrm{HR}$ Newcastle disease $\left(\mathrm{V}_{4} \mathrm{HR}-\mathrm{ND}\right)$ vaccine in broiler birds in Bangladesh. Indian. J. 
Poult. Sci. 39(5): 365-368.

Ratnaparkhe, P., Tanwani, S.K. and Pathak, P.N. 1981. Comparative immune response and antibody response of CDF-66 strain of New scastle disease virus with other four lentogenic vaccine strains. Indian J. Poult. Sci. 16: 235242.

Reed, L.V. and Muench, H. 1938. A simple method of estimating fifty per cent end points. Am. J. Hyg. 27:493-497.

Reetha, T.L., Rajeswar, J.J., Dorairajan, N. and Thangamani, R. 2001. Assessment of immune response in chicken in different commercially available Ranikhet disease vaccines by ELISA test.Indian J. Anim. Hlth. 40(1): 9-12.

Reynolds, D.L. and Maraqa, A.D. 2000. Protective immunity against Newcastle disease: the role of cell-mediated immunity. Avian Dis.44: 145-154.

Russell, P.H. and Ezeifeka, G.O. 1995. The Hitchner B1 strain of Newcastle disease virus induces high levels of $\operatorname{IgA}, \operatorname{IgG}$ and $\operatorname{IgM}$ in newly hatched chicks. Vaccine. 13: 61- 66.

Satyanarayana, A. and Reddy, A.M.K. 1977.

Pattern of development and duration of immunity in chicks protected with $\mathrm{F}$ strain Ranikhet disease vaccine. Indian Vet. J. 54: 509-516.

Sharma, K. and Singh, G. 1986. A note on serologic and immunologic response to Ranikhet Disease F strain vaccine in young broiler chicks. Poult. Adv.19: 3536.

Shuaib, M., Khan, H., Sajid-Ur-Rehman and Ashfaque, M. 2006. Humoral immune response to Newcastle disease vaccine (LaSota strain) in broiler. International J. Poult. Sci. 5(5): 411-414.

Spradbrow, P.B., Samuel, J.L. and Ibrahim, A.L. 1987. Serological response of chickens to oral vaccination with Newcastle disease virus.Vet. Microbial.16: 255-262.

Tanwani, S.K. and Malik, B.S. 1978. A comparative study of immune \& antibody response of lentogenic strain CDF-66 and other vaccine strain of Ranikhet disease virus. Indian. Vet. J. 55: 267-278.

Zoth, S.C., Gomez, E., Carrillo, E. and Berinstein, A. 2008. Locally produced mucosal IgG in chickens immunized with conventional vaccines for Newcastle disease virus. Brazilian J. Med. Biol. Res. 41: 318-323.

\section{How to cite this article:}

Rajesh Singathia, Ravindra Sharma and Satishkumar Batra. 2019. Systemic and Local Humoral Immune Response against F-1 and LaSota Strains of New Castle Disease Virus in Chicken. Int.J.Curr.Microbiol.App.Sci. 8(09): 194-203. doi: https://doi.org/10.20546/ijcmas.2019.809.025 